time that has been lost. However, the question of the representation of hospital junior staff within the B.M.A. will still be on its agenda, as it will be on that of the Central Committee for Hospital Medical Services. The Association, too, must always take notice of the interests of the sections of its membership, and discontent among any group should never be accepted as irremediable. The most cogent argument for having the one standing committee (the Central Committee for Hospital Medical Services) to represent the interests of all hospital medical staff instead of having one committee for seniors and one for juniors-as the Hospital Junior Staffs Group Council wanted-is that it is impossible in any major matter to separate the interests of one from those of the other. Events over the next few months, when decisions affecting the whole profession will have to be taken, may well serve to emphasize this identity of interest in a practical way. It also tends to be forgotten that common to all doctors in all grades is an obligation to provide the best possible service to the sick. The give-and-take and comradeship among doctors in their clinical work should serve as an example of what might be achieved in relationships in other spheres.

In any event, future discussions on the representation of hospital junior staff may be expected to be conducted in a calmer atmosphere in which considerations of where interests meet are more likely to predominate over those of where they differ. If there is a convincing case for having a standing committee for hospital junior staff within the B.M.A. it will be best made with the aid of reason and not of threats.

\section{Antibiotics in Animals}

The administration of antibiotics to animals has been under fire for some years as a source of drug resistance in bacteria communicable to man. Because this resistance is transmissible there was an evident danger that it might come to include the purely human pathogens of the enteric group. In 1966 the Agricultural and Medical Research Councils' Joint Committee on Antibiotics in Animal Feeding (Netherthorpe Committee) concluded that permitted uses of antibiotics in animal feeds-namely, those of penicillin and tetracyclines in pigs and poultry-could not be held responsible for this situation, and recommended a general inquiry embracing other uses of antibiotics in animals. This led to the appointment in July 1968 of the Joint Committee on the Use of Antibiotics in Animal Husbandry and Veterinary Medicine, whose report ${ }^{1}$ was published on 20 November. A ministerial statement on the same day accepted the main recommendations of the report and promised that they would be implemented " as quickly as possible."

On one aspect of this subject the report is disappointing. It was certainly a hope of the Netherthorpe Committee that inquiry would be made into abuses as well as uses. Permitted uses as food supplements for animals are severely restricted as to type and age of the animal and quantity administered, and there were strong suspicions and indeed some evidence that the regulations were being flouted. The report has nothing to say on this, nor does it attempt to distinguish between the effects, in relation to bacterial resistance, of low-level supplementation in animal feeding-stuffs and the higher scale of dosage used for the prevention or treatment of enteritis. It does acknowledge that the multiple drug resistance in Salmonella typhimurium in calves which is the main cause of present apprehension was largely the result of futile efforts at mass prophylaxis in the face of an epidemic. "Human experience suggests that antibiotics have no place in attempts to control the spread of intestinal infections, and we expect that suitable studies would show this to be equally true in animals." The report also condemns administration of antibiotics in subtherapeutic doses to "stressed" animals, whatever they may be (and the report is itself doubtful).

The hazards to man are fairly assessed. That presented by the recent prolonged epidemic in calves, of which $E$. S. Anderson gave a full account last year, ${ }^{2}$ is incontestable: there were over 500 human cases of this infection. The annual incidence of salmonella infections, almost all derived from animal sources, is rather less than one per thousand of the population, but it is undesirable that drug resistance should be transferred to human bacteria in this way. On the other hand most animal bacteria contaminating human food are not pathogens with an exceptional capacity for multiplying in their new environment, but commensals. The capacity of these for establishing themselves in the human bowel was conjectural until the recent studies of $\mathrm{H}$. Williams $\mathrm{Smith}^{3}$ found it to be very small. In numerous experiments animal strains of Escherichia coli swallowed in unnaturally large numbers were recoverable from human faeces either not at all or for very few days, and very little resistance was found to have been transferred to human types of $E$. coli. The present report acknowledges repeatedly that transmission of drug resistance by such organisms is unlikely.

Nevertheless, a hazard remains, though by comparison with the effects of human medication it may be small. While acknowledging this in paragraph 8.11 (p. 39), the committee evidently felt unable to take the responsibility of acquiescing in the present situation, and, having taken that decision, they had no alternative to proposing that all present feed supplementation with medically used antibiotics should cease. This involves not only tetracyclines and penicillin-though the evidence that penicillin promotes resistance is admittedly very slender-but also tylosin, sulphonamides, and nitrofurans. These are now categorized as "therapeutic" drugs, available only on prescription, and a new class of "feed " antibiotics is to be established which can be used as growth-promoting supplements.

Here the Netherthorpe Committee is quoted as having in 1962 expressed the desirability of adopting non-medical antibiotics for this purpose and having defined three conditions which they must fulfil if they are so to be used. These conditions the report accepts. It is, however, in error in stating that at that time no antibiotic fulfilling these conditions was available. Bacitracin, which the report specifically commends, was already a permitted feed additive in ten countries in $1961 .^{4}$ Apart from copper and arsenic compounds, which also have some growth-promoting effect, the only replacements suggested for the now prohibited feed additives are bacitracin and virginiamycin. The report does not mention that each of these antibiotics is manufactured only abroad and will therefore have to be imported, whereas the drugs used at present are made at home. Reflection on these drastic proposals brings a growing conviction that they should not be imple-

\footnotetext{
Report of the foint Committee on the Use of Antibiotics in Animal Husbandry and Veterinary Medicine, 1969, Cmnd. 4190. London, H.M.S.O.

Anderson, E. S., British Medical fournal, 1968, 3, 333.

3 Anderson, E. S., British Medical fourna

4 The Public Health Aspects of the Use of Antibiotics in Food and Feedstuffs, W.H.O. Technical Report Series, 1963, No. 260.
} 
mented without further discussion by experts other than the nine members of the committee responsible for them. If this should take place, attention is likely to be focused on the possible retention of penicillin as a feed additive. The evidence against it is so questionable that its condemnation cannot be justified without further study.

The report proposes that veterinarians should retain full freedom in prescribing antibiotics and other antibacterial drugs, including the much disputed chloramphenicol, resistance to which in the typhoid bacillus is the spectre motivating present fears. It is to be hoped that the conclusions of the committee about the futility of trying to combat enteritis by mass antibiotic prophylaxis will be brought forcefully to the notice of the veterinary profession. Many other excellent but long-term recommendations are made with a view to the better study of epidemiology in animals and to improvements in methods of animal husbandry. It is well recognized that a certain type of trade in very young calves was largely responsible for recent disasters, and that intensive methods of rearing also carry risks which need to be intelligently countered. The use of antibiotics in feeding-stuffs is to be extended to calves. Antibiotic residues in foods are considered unimportant, but the search for a "marker" to denote the presence of antibiotics in milk from cows treated for mastitis should be continued (all the dyes so far tried are unsuitable in some way). It is proposed that under the Medicines Act one committee should have " overall responsibility for the whole field of use of antibiotics and related substances whether in man, animals, food preservation, or for other purposes." These and other proposals in this far-reaching document will give the departments concerned material for consideration for some years to come.

\section{Brucellosis Still Spreading}

Though brucellosis is a preventable disease, insufficient effort is being made to prevent it in Britain. The Scandinavian countries are clear of it, and many others are rapidly becoming so. In the United Kingdom only Northern Ireland has a satisfactory scheme of eradication, and the result is that over $97 \%$ of the eligible herds there have been certified as free of brucellosis. Yet in Great Britain up to the end of October this year only $6 \%$ of the herds had been registered as accredited. ${ }^{1}$ The figure for Scotland separately is $7 \% .^{1}$

As the disease in man is not generally notifiable, is difficult to diagnose, and is not often lethal, its prevalence in the community is impossible to estimate at all precisely. A figure of somewhere between 100 and 1,000 cases or even more a year has been discussed. ${ }^{2}$ At present informed opinion puts the total at about $800-1,000$. Though deaths are uncommon they do occur from time to time. In 1967, for instance, the latest year for which figures have been published for England and Wales, a man aged 60 and a woman of the same age died of the disease-the first in Lancashire and the second in Cheshire. ${ }^{3}$ But though death is uncommon disability can be severe, with long-continued weakness, malaise, sweating, and pains in the head, muscles, joints, and abdomen. Fever, rigors, and mental disturbance are reported in some cases. The signs and symptoms have been well reviewed by Dalrymple-Champneys ${ }^{4}$ and many cases reported on in the last two decades..$^{5-8}$
Man acquires infection mainly from cattle nowadays and to a much less extent from milk. This is because about $97 \%$ of the milk sold is heat-treated, which gives complete protection against transmission of brucellosis. But as the untreated $3 \%$ represents some 50 million gallons a year there is little doubt that some of this milk does spread the disease. ${ }^{\circ}$ Consequently, important though the provision of safe milk is, the main attack on brucellosis must come through its eradication from cattle. The failure of successive Governments to tackle the problem effectually has been criticized before in these columns, and the latest figures now given in Parliament ${ }^{1}$ show how backward Britain still is.

Nor is the slowness of the present scheme any guarantee of sureness. In fact there must be some anxiety lest the opposite is true. At page 550 of the B.M.7. this week Dr. R. J. Henderson describes how some farmers are deliberately selling and unwittingly buying cows infected with Brucella abortus. It should be stressed that his report is not in any sense an indictment of the farming community, the great majority of whom deplore and shun the practices he describes. But honesty can be expensive in farming as in other walks of life, and when a farmer who is struggling along finds that a cow he has bought comes out with brucellosis he is apt to react like not too scrupulous people who find a foreign coin in their change-pass it on quickly. Some farmers, in fact, lacking the financial resources or the craftsmanship that their occupation demands, are for ever buying cows in milk and selling them when they no longer yield a profit instead of going to the trouble of building up a milking herd over the years. Moreover, as the scheme for building up accredited herds progresses, so the number of infected animals being discovered and put up for sale increases. The result may well be, as Dr. Henderson suggests, that the number of infected herds will thus grow instead of diminish.

Though Dr. Henderson refers to the accredited herds scheme as the British eradication scheme, he is paying it a compliment it does not deserve. There is none of the compulsory detection and slaughter of cattle which other countries have carried out. A farmer in the accredited herds scheme who finds that one of his cows is infected must slaughter it if he wishes to remain in the scheme, but it is to his advantage to sell the animal in the open market. A true eradication scheme means compulsory measures to detect and slaughter infected cattle, with proper compensation to the farmer. All good farmers would welcome such a scheme, but successive Governments have temporized owing to the expense, and to give them their due they have been occupied in getting other diseases eradicated also, notably tuberculosis. But when does the application of a known remedy to prevent a substantial number of cases every year of a disabling and occasionally lethal disease cease to be too expensive ? As the disease is transmitted mainly by infected cattle, the chief sufferers from it are to be found in the farming community and their allies such as veterinary surgeons, so that in that sense it is largely an occupational disease. And it would certainly be hard to think of another occupation in which every year some

British Medical fournal, 1969, 4, 504.

2 British Medical fournal, 1966, 2, 63.

The Registrar General's Statistical Review of England and Wales, he Registrar General's Statistical Review of England
Part 1, Tables, Medical. London, H.M.S.O. 1967.

Dalrymple-Champneys, Sir W., Lancet, 1950, 1, 429, 477.

Dart, F. D., Morgan, A., and Lacey, B., British Medical fournal, 1951, 1, 1048.
. H., and Stote, C. L., British Medical fournal, 1953, 1, 914. 6 Grant, G. H., and Stote, C. L., British Medical fournal,
7 Wallis, H. R. E., British Medical fournal, 1957, 1, 617.

- Wallis, H. R. E., British Medical fournal, 1957, 1, 617.

On the State of the Public Health: Annual Report of the Chief Medical Officer of the Ministry of Fealth for the Year 1967. London. H.M.S.O. 1968.

.

